\title{
Detection of Individual RNA in Fixed Cells and Tissues by Chromogenic ISH
}

\author{
Meng Jiang, Chen Lin and Rongqin Ke*
}

Center for Precision Medicine, School of Biomedical Sciences and School of Medicine, Huaqiao University, Quanzhou, Fujian, 362021, China

*For correspondence: rke@hqu.edu.cn

\begin{abstract}
[Abstract] Visualization of RNA molecules in situ helps to better understand the functions of expressed genes. Currently, most conventional in situ hybridization methods for visualization of individual RNAs are based on fluorescence detection. Herein we present a chromogenic in situ hybridization protocol for visualization of single RNA molecules in fixed cells and tissues. The protocol is based on padlock probing and rolling circle amplification to generate detectable chromogenic signal from single RNA molecules. Chromogenic signal can avoid background autofluorescence and can be preserved for a longer period than fluorescence signal.
\end{abstract}

Keywords: Chromogenic in situ hybridization, Gene expression, Padlock probe, Rolling circle amplification

[Background] The abundance and spatial location of expressed RNA molecules indicates the physiological and pathological status of cells and tissues. Therefore, there is an increasing interest for in situ RNA detection. Compared to conventional in situ hybridization methods, novel methods that can detect RNA at individual molecule level are more sensitive and specific (Crosetto et al., 2015). These methods include single molecule fluorescence in situ hybridization (smFISH) (Femino et al., 1998), methods based on rolling circle amplification (Larsson et al., 2010), hybridization chain reaction (HCR) (Shah et al., 2016), and branched DNA (bDNA) technology (Wang et al., 2012; Battich et al., 2013). Current methods for individual RNA in situ detection assays are normally readout as fluorescence signal, which offers good sensitivity and is easy to multiplex. Chromogenic readout is often used in conventional RNA ISH assays, providing stable signal that can be stored for long period of time, and is not affected by autofluorescence or photobleaching. Therefore, we introduce the single molecule chromogenic in situ hybridization (smCISH) assay that enables sensitive and specific detection of individual RNA in fixed cells and tissues (Jiang et al., 2019). Our protocol is based on padlock probing and rolling circle amplification (Nilsson et al., 1994; Banér et al., 1998). First, padlock probe is designed to directly bind to target RNA specifically. After padlock probe hybridization, probe circularization is performed using SplintR DNA ligase. The closed circle is RNA-templated ligation of its two ends. Next, an RCA primer is hybridized to the circularized padlock probe to initiate rolling circle amplification reaction. The padlock probe is then amplified into its complementary concatenated form to generate RCP. HRP labeled detection probes are then hybridized to the RCP. Finally, chromogenic signal is developed using $\mathrm{H}_{2} \mathrm{O}_{2}$ and 3,3'-Diaminobenzidine (DAB) to generate brown insoluble dots from individual RCPs, which 
corresponds to single RNA molecules. Our results show that single molecule chromogenic in situ hybridization assay can count and localize individual RNA molecules in fixed cells and tissue samples.

\section{Materials and Reagents}

1. Secure-Seal hybridization chamber, $9 \mathrm{~mm}$ diameter, $0.8 \mathrm{~mm}$ deep (Containing seal tabs, Thermo Scientific, catalog number: S24732)

2. EasYFlask $25 \mathrm{~cm}^{2}$ (Thermo Scientific Nunc, catalog number: $156340-R O S$ )

3. Serological Pipette (Thermo Scientific Nunc, $2 \mathrm{ml}, 5 \mathrm{ml}, 10 \mathrm{ml}, 50 \mathrm{ml}$ )

4. Cell culture Dish, $150 \mathrm{~mm} \times 20 \mathrm{~mm}$ (Thermo Scientific Nunc, catalog number: 168381-ROS)

5. Adhesion Microscope Slides (Citotest, catalog number: 188105)

6. $15 \mathrm{ml}$ Conical Centrifuge Tubes (Thermo Scientific Nunc, catalog number: 339650-SPL)

7. $50 \mathrm{ml}$ Conical Centrifuge Tubes (Thermo Scientific Nunc, catalog number: $339652-\mathrm{SPL}$ )

8. Filtered Pipette Tip (QSP, 0.1-10 $\mu \mathrm{l}, 2-20 \mu \mathrm{l}, 10-100 \mu \mathrm{l}, 20-200 \mu \mathrm{l}, 100-1,000 \mu \mathrm{l}$ )

9. $0.2 \mathrm{ml} \mathrm{PCR}$ Tubes (AXYGEN, catalog number: PCR-02-C)

10. $1.5 \mathrm{ml}$ Microtubes (AXYGEN, catalog number: MCT-150-C)

11. $0.22 \mu \mathrm{m}$ membrane filter (Millipore, catalog number: SLGP033RS)

12. HER2 padlock probe 5'ATTACTTGCAGGTTCTTTCCTTTTACGA CCTCAATGCTGCTGCTGTACTACTCTTCAGAATT CGTCCCCGG, underline: target hybridization sequences and detection probe complementary part, bold italics: RCA primer binding part) (Synbio Tech, China)

13. ACTB padlock probe (sequence: 5'-CTGTGCTCGCGGGGCGTTCCTTTTACGA GCTGCTGCTGTACTACTCTTGGCAAAGGCGAGGCT, underline: target hybridization sequ ences and detection probe complementary part, bold italics: RCA primer binding part) (Synbio Tech, China)

14. RCA primer (sequence: 5'-ACAGCAGCAGCATTGAGGTC) (Synbio Tech, China)

15. HRP labeled detection probe (sequence: 5 ' HRP-CCTCAATGCTGCTGCTGTACTAC) (TaKaRa)

16. Pepsin (Sigma-Aldrich, catalog number: $\mathrm{P} 7012-1 \mathrm{G}$ ), store at $-20^{\circ} \mathrm{C}$

17. Fetal Bovine Serum (Hyclone, catalog number: 10270-106), store at $-20^{\circ} \mathrm{C}$

18. Trypsin (Hyclone, catalog number: $\mathrm{SH} 30042.01$ ), store at $-20{ }^{\circ} \mathrm{C}$

19. ATP, $100 \mathrm{mM}$ Solution (Thermo Scientific, catalog number: R0441), store at $-20^{\circ} \mathrm{C}$

20. T4 Polynucleotide Kinase, $10 \mathrm{U} / \mu \mathrm{l}$ (Thermo Scientific, catalog number: EK0032, containing PNK buffer $\mathrm{A}$ ), store at $-20^{\circ} \mathrm{C}$

21. dNTP Set, $100 \mathrm{mM}$ Solutions (Thermo Scientific, catalog number: R0182), store at $-20^{\circ} \mathrm{C}$

22. SplintR Ligase, $25 \mathrm{U} / \mu \mathrm{l}$ (NEB, catalog number: M0375L), store at $-20^{\circ} \mathrm{C}$

23. phi29 DNA Polymerase, $10 \mathrm{U} / \mu \mathrm{l}$ (Thermo Scientific, catalog number: EP0094), store at $-20^{\circ} \mathrm{C}$

24. BSA, $20 \mathrm{mg} / \mathrm{ml}$ (NEB, catalog number: B9000S), store at $-20{ }^{\circ} \mathrm{C}$

25. RiboLock RNase Inhibitor, $40 \mathrm{U} / \mu \mathrm{l}$ (Thermo Scientific, catalog number: EO0384), store at $-20^{\circ} \mathrm{C}$

26. Tween-20 (Sigma-Aldrich, catalog number: P9416-100ML), store at room temperature (RT) 
27. Triton X-100 (Sigma-Aldrich, catalog number: T8787-100ML), store at RT

28. $\mathrm{NaOH}$ (Sigma-Aldrich, catalog number: 795429-500G), store at RT

29. $\mathrm{KCl}$ (Sigma-Aldrich, catalog number: P9541-500G), store at RT

30. $\mathrm{NaCl}$ (Sigma-Aldrich, catalog number: $\mathrm{S} 3014-1 \mathrm{kG}$ ), store at RT

31. $\mathrm{Na}_{2} \mathrm{HPO}_{4}$ (BBI LIFE SCIENCES, catalog number: A610404-0500), store at RT

32. $\mathrm{KH}_{2} \mathrm{PO}_{4}$ (Sangon Biotech, catalog number: A100781-0500), store at RT

33. Sodium iodate (BBI LIFE SCIENCES, catalog number: A600859), store at RT

34. Aluminum potassium sulfate dodecahydrate (Sangon Biotech, catalog number: A500755), store at RT

35. Glycerol (Sigma-Aldrich, catalog number: G9012-100ML), store at RT

36. Hematoxylin (Sigma-Aldrich, catalog number: H3136-25G), store at RT

37. Neutral balsam mounting medium (BBI LIFE SCIENCES, catalog number: E675007), store at RT

38. Xylene (XILONG SCIENTIFIC, catalog number: 33535-500ML), store at RT

39. Ethanol (Macklin, catalog number: E809061-500 ML), store at RT

40. Acetate (Macklin, catalog number: A801295-500 ML), store at RT

41. Hydrochloric acid (SCR, catalog number: 10011018), store at RT

42. DEPC (Sigma-Aldrich, catalog number: D5758-25ML), store at $4{ }^{\circ} \mathrm{C}$

43. Paraformaldehyde (Sigma-Aldrich, catalog number: $16005-1 K G-R$ ), store at $4{ }^{\circ} \mathrm{C}$

44. Formamide (Sigma-Aldrich, catalog number: F9037-100ML), store at $4{ }^{\circ} \mathrm{C}$

45. 20x SSC buffer (Sigma-Aldrich, catalog number: S6639), store at $4{ }^{\circ} \mathrm{C}$

46. 1x Phosphate Buffered Saline (Hyclone, catalog number: $\mathrm{SH} 30256.01$ ), store at $4{ }^{\circ} \mathrm{C}$

47. DNase/RNase-Free Water (Solarbio, catalog number: R1600), store at $4{ }^{\circ} \mathrm{C}$

48. Hydrogen peroxide solution, $30 \mathrm{wt} . \%$ in $\mathrm{H}_{2} \mathrm{O}$ (Macklin, catalog number: $\mathrm{H} 811240-500 \mathrm{ml}$ ), store at $4{ }^{\circ} \mathrm{C}$

49. DAB Immunohistochemistry Color Development Kit (BBI LIFE SCIENCES, catalog number: EP670033), store at $-20^{\circ} \mathrm{C}$

50. EDTA (Sigma-Aldrich, catalog number: RDD017-500G), store at RT

51. Serum-free medium, DMEM/HIGH GLUCOSE (Hyclone, catalog number: SH30022.01), store at $4{ }^{\circ} \mathrm{C}$

52. Penicillin-Streptomycin (Hyclone, catalog number: SV30010), store at $-20^{\circ} \mathrm{C}$

53. Culture media (50 ml) (see Recipes)

54. 10x PBS (500 ml), pH 6.8 (see Recipes)

55. 1x DEPC-PBS (1 L), pH 7.4 (see Recipes)

56. $1 \times$ DEPC-PBST (1 L) (see Recipes)

57. $4 \%(\mathrm{w} / \mathrm{v})$ PFA (500 $\mathrm{ml}$ ) (see Recipes)

58. $1 \mathrm{X}$ TE buffer (100 ml), pH 8.0 (see Recipes)

59. $0.5 \%(\mathrm{v} / \mathrm{v})$ Triton $\mathrm{X}-100(5 \mathrm{ml})$ (see Recipes)

60. $3 \%(w / v) \mathrm{H}_{2} \mathrm{O}_{2}$ solution (50 $\mu \mathrm{l}$ ) (see Recipes) 
61. $2 x$ hybridization buffer $(5 \mathrm{ml})$ (see Recipes)

62. Washing buffer (15 ml) (see Recipes)

63. $2 x$ detection buffer $(5 \mathrm{ml})$ (see Recipes)

64. Staining buffer (50 $\mu$ l) (see Recipes)

65. $0.1 \%$ hydrochloric acid-ethanol $(5 \mathrm{ml}$ ) (see Recipes)

66. Hematoxylin Staining Solution $(50 \mathrm{ml})$ (see Recipes)

67. $25 \mathrm{mM}$ dNTPs (100 $\mu \mathrm{l})$ (see Recipes)

\section{Equipment}

1. Vortex Mixers (MIULAB, model: MIX-25P)

2. Microcentrifuge (MIULAB, model: Mini-6K)

3. Magnetic stirrer (IKA, RCT basic)

4. $\mathrm{pH}$ meter (OHAUS, model: starter3100)

5. PCR machine (BIOER, model: TC-XP)

6. Analytical balance (OHAUS, model: AS220.R2)

7. Pipette (Eppendorf AG, Research plus)

8. Cell culture incubator (Esco, model: CCL-170B-8)

9. Biosafety cabinet (Esco, model: AC2-4S1)

10. Ultra-low temperature freezer (Thermo, model: DW-86L338)

11. Freezer (Siemens, model: KG32EV2S0C)

12. Electro-heating standing-temperature cultivator (ENXIN, model: DRP-9052)

13. Microscope (Leica, model: DM6B, equipped with a DFC7000T camera)

\section{Software}

1. CellProfiler

2. GraphPad Prism

\section{Procedure}

A. Cell culture and sample preparation

1. Pre-warm $2 \mathrm{ml} 1 \times$ DEPC-PBS, $23 \mathrm{ml}$ culture media and $0.8 \mathrm{ml} 0.25 \%(\mathrm{w} / \mathrm{v})$ trypsin-EDTA to $37^{\circ} \mathrm{C}$.

2. Remove the used culture media in the cell culture flask (take $25 \mathrm{~cm}^{2}$ flask for example).

3. Wash briefly with $2 \mathrm{ml} 1 \times$ DEPC-PBS. Aspirate PBS.

4. Add $0.8 \mathrm{ml} 0.25 \%(\mathrm{w} / \mathrm{v})$ trypsin-EDTA into flask and cover the cells.

5. Check the cells with inverted microscope to be sure that most of the cells are rounded up, but still attached to the flask. Carefully remove trypsin. 
6. Add $3 \mathrm{ml}$ culture media to the flask, suspend the cells from attached cell layer and mix them well by pipetting.

7. Put 5 slides into a Petri dish and add $20 \mathrm{ml}$ culture media into it to cover the slides.

8. Seed the resuspended cells on slides.

9. Rest for at least 10 min until resuspended cells subside on the slides.

10. Transfer the Petri dish into the cell culture incubator $\left(37^{\circ} \mathrm{C}, 5 \% \mathrm{CO}_{2}\right)$.

11. Culture the cells until they reach $80 \%$ confluence $(12-48 \mathrm{~h})$.

12. After $12-48 \mathrm{~h}$ incubation, remove and discard the culture media.

13. Wash 3 times with $25 \mathrm{ml}$ 1x DEPC-PBS for 3 min each.

14. Add $25 \mathrm{ml} 4 \%$ (w/v) PFA into the Petri dish to cover the slides for $30 \mathrm{~min}$ at RT.

15. Wash twice with $25 \mathrm{ml} 1 \times$ DEPC-PBS for 3 min each.

16. Perform dehydration using an ethanol series of $70 \%, 85 \%$, and ethanol absolute for 5 min each. Air dry.

Note: The sample slides can be stored at $-80^{\circ} \mathrm{C}$ until used.

B. Pretreatments

1. Phosphorylate padlock probes before use. Prepare $50 \mu \mathrm{l}$ mix containing $38 \mu \mathrm{l}$ DEPC- $\mathrm{H}_{2} \mathrm{O}, 1 \mu \mathrm{l}$ padlock probes $(100 \mu \mathrm{M}), 5 \mu \mathrm{l}$ PNK buffer A (10x), $5 \mu \mathrm{l}$ ATP $(10 \mathrm{mM}), 1 \mu \mathrm{l} \mathrm{T4}$ polynucleotide kinase $(10 \mathrm{U} / \mathrm{\mu l})$ in the $0.2 \mathrm{ml} \mathrm{PCR}$ Tubes.

2. Incubate the above mixture at $37^{\circ} \mathrm{C}$ for $30 \mathrm{~min}$ and $65^{\circ} \mathrm{C}$ for $10 \mathrm{~min}$ in the PCR machine.

Note: For formalin-fixed, paraffin-embedded pathological tissue sections, perform pretreatments procedures 3 to 20, expect 17 and 18. For cell samples, perform pretreatments procedures 14 to 20.

3. Bake the slide at $60{ }^{\circ} \mathrm{C}$ for $30 \mathrm{~min}$.

4. Put the slide into the xylene for $15 \mathrm{~min}$ and another fresh xylene for $10 \mathrm{~min}$, respectively.

5. Put the slide into ethanol absolute twice, $95 \%$ ethanol twice, and $70 \%$ ethanol twice for $2 \mathrm{~min}$ each time.

6. Treat the slide with DEPC- $\mathrm{H}_{2} \mathrm{O}$ for 5 min to complete rehydration.

7. Wash with DEPC-PBS for 2 min.

8. Perform the fixation procedure with $4 \%$ (w/v) PFA in DEPC-PBS for $10 \mathrm{~min}$.

9. Wash with DEPC-PBS for 2 min.

10. Put the slide into the solution of $0.1 \mathrm{mg} / \mathrm{ml}$ pepsin in $0.1 \mathrm{M} \mathrm{HCl}$ for $30 \mathrm{~min}$ at $37^{\circ} \mathrm{C}$.

11. Wash with DEPC- $\mathrm{H}_{2} \mathrm{O}$ for $5 \mathrm{~min}$.

12. Wash with DEPC-PBS for 2 min.

13. Dehydrate the slide by an an ethanol series of $70 \%, 85 \%$, and ethanol absolute for 1 min each.

14. Air dry.

15. Assemble the $9 \mathrm{~mm}$ diameter and $0.8 \mathrm{~mm}$ depth Secure-Seal hybridization chamber to the surface of the slide on the side where the samples are (Figure 1). All the following incubation step take place in the chamber with a volume of $50 \mu$ l. 


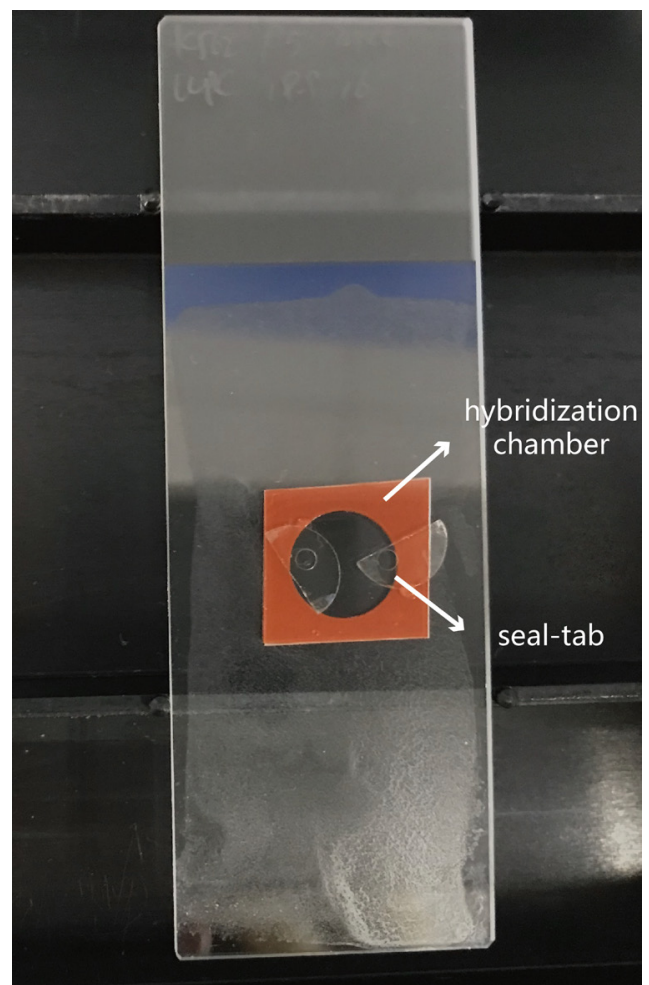

Figure 1. Assemble hybridization chamber to the surface of slide where the samples are.

Place a seal-tab over each filling port to prevent evaporation of the solutions and the drying out of the specimen.

16. Rinse the cell sample with DEPC-PBS with $0.05 \%$ Tween-20 (DEPC-PBST).

17. Add $50 \mu \mathrm{l} 0.5 \%(\mathrm{v} / \mathrm{v})$ Triton X-100 (in DEPC-PBS) into the chamber to permeabilize the cells for 10 min at RT.

18. Wash 3 times with $1 \times$ DEPC-PBST.

19. Apply $50 \mu \mathrm{l} 3 \%(\mathrm{w} / \mathrm{v}) \mathrm{H}_{2} \mathrm{O}_{2}$ solution to the sample for $15 \mathrm{~min}$ at RT to block endogenous peroxidases.

20. Wash 3 times with DEPC-PBST.

C. Padlock probe hybridization

1. Prepare $50 \mu \mathrm{l}$ padlock probe hybridization mix containing $22.5 \mu \mathrm{l}$ DEPC- $\mathrm{H}_{2} \mathrm{O}, 25 \mu \mathrm{l} 2 \mathrm{x}$ hybridization buffer and $2.5 \mu$ phosphorylated padlock probe $(2 \mu \mathrm{M}$, from B2).

2. Add the mix into the chamber and incubate for $2 \mathrm{~h}$ at $37^{\circ} \mathrm{C}$.

3. Wash 3 times with washing buffer for 5 min each.

4. Wash 3 times with DEPC-PBST.

D. Padlock probe ligation

1. Prepare $50 \mu \mathrm{l}$ padlock probe ligation mix containing $6.5 \mu \mathrm{LEPC}-\mathrm{H}_{2} \mathrm{O}, 31.25 \mu \mathrm{l} 80 \%(\mathrm{v} / \mathrm{v})$

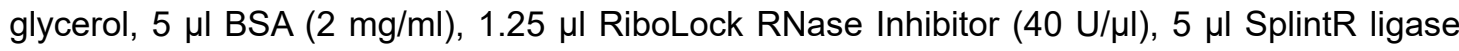
reaction buffer (10x) and $1 \mu$ S SplintR ligase $(25 \mathrm{U} / \mu \mathrm{l})$. 
2. Add the mix into the chamber and incubate for $1 \mathrm{~h}$ at $37^{\circ} \mathrm{C}$.

3. Wash 3 times with washing buffer for 5 min each.

E. RCA primer hybridization

1. Prepare $50 \mu \mathrm{l}$ RCA primer hybridization mix containing $20 \mu \mathrm{LEPC}-\mathrm{H}_{2} \mathrm{O}, 25 \mu \mathrm{l} 2 \mathrm{x}$ hybridization buffer and $5 \mu \mathrm{l}$ RCA primer $(10 \mu \mathrm{M})$.

2. Add the mix into the chamber and incubate for $30 \mathrm{~min}$ at $37^{\circ} \mathrm{C}$

3. Wash 3 times with washing buffer for 5 min each.

4. Wash 3 times with DEPC-PBST.

F. RCA

1. Prepare $50 \mu \mathrm{l} \mathrm{RCA} \mathrm{mix} \mathrm{containing} 26.75 \mu \mathrm{l}$ DEPC- $\mathrm{H}_{2} \mathrm{O}, 5 \mu \mathrm{l} 50 \%$ (v/v) glycerol, $2 \mu \mathrm{l}$ dNTP $(25$ $\mathrm{mM}$ ), $5 \mu \mathrm{l} \mathrm{BSA}(2 \mathrm{mg} / \mathrm{ml}), 1.25 \mu \mathrm{l}$ RiboLock RNase Inhibitor ( $40 \mathrm{U} / \mu \mathrm{l}), 5 \mu \mathrm{l}$ phi29 DNA polymerase buffer (10x) and $5 \mu \mathrm{l}$ phi29 polymerase $(10 \mathrm{U} / \mu \mathrm{l})$.

2. Add the mix into the chamber and incubate for $16-18 \mathrm{~h}$ at RT.

3. Wash 3 times with washing buffer for 5 min each.

4. Wash 3 times with DEPC-PBST.

G. RCA products detection

1. Prepare $50 \mu \mathrm{l} \mathrm{RCA}$ products detection mix containing $10 \mu \mathrm{LEPC}-\mathrm{H}_{2} \mathrm{O}, 25 \mu \mathrm{l} 2 \mathrm{x}$ detection buffer, $12.5 \mu \mathrm{l} 80 \%(\mathrm{v} / \mathrm{v})$ glycerol and $2.5 \mu \mathrm{l} \mathrm{HRP-labeled} \mathrm{detection} \mathrm{probe}(2 \mu \mathrm{M})$.

2. Add the mix into the chamber and incubate for $30 \mathrm{~min}$ at RT.

3. Wash 3 times with DEPC-PBST.

H. Staining and mounting

1. Incubate the sample with staining solution for 3 to 8 min depending on the color development.

2. Wash 3 times with DEPC- $\mathrm{H}_{2} \mathrm{O}$.

3. Stain the nuclei in Hematoxylin staining solution for $1 \mathrm{~min}$.

4. Wash 3 times with DEPC- $\mathrm{H}_{2} \mathrm{O}$.

5. Differentiate with $0.1 \%$ hydrochloric acid-ethanol for $1 \mathrm{~min}$.

6. Wash 3 times with DEPC- $\mathrm{H}_{2} \mathrm{O}$.

7. Place slide in $1 \times$ DEPC-PBS for $1 \mathrm{~min}$.

8. Wash 3 times with DEPC- $\mathrm{H}_{2} \mathrm{O}$.

9. Remove the chamber and rinse in running tap water for $5 \mathrm{~min}$.

10. Dehydrate the slide by an ethanol series of $70 \%, 85 \%$, and ethanol absolute for 1 min each.

11. Mount the slide with $15-20 \mu$ neutral balsam mounting medium.

I. Image acquisition

1. Acquire images with bright-filed microscope using the $40 x$ objective. 
2. In images, brown dots are detected individual mRNA molecules and nuclei are shown in blue (Figures 2 and 3).

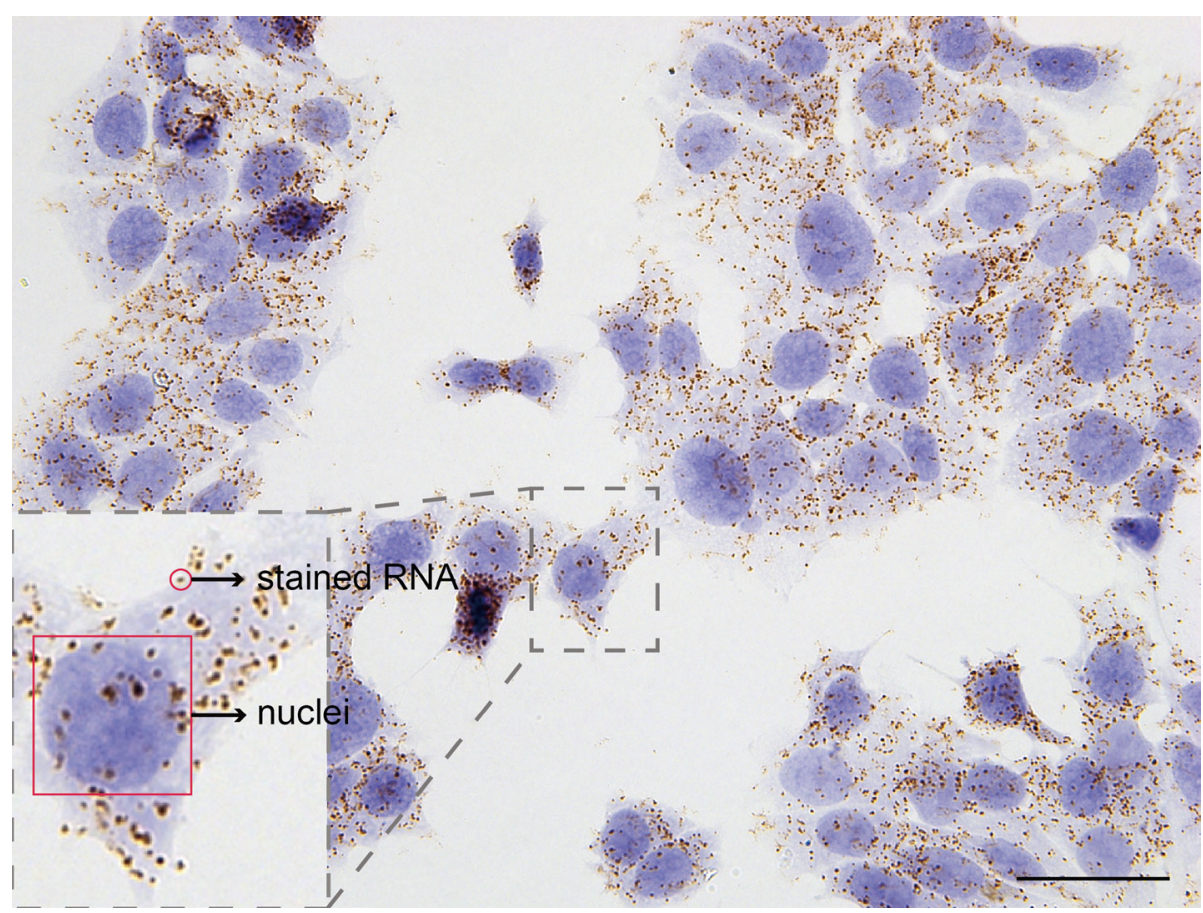

Figure 2. Detection of ACTB mRNA molecules in MCF-7 cells. Scale bar $=40 \mu \mathrm{m}$. 


\section{bĭo-protocol

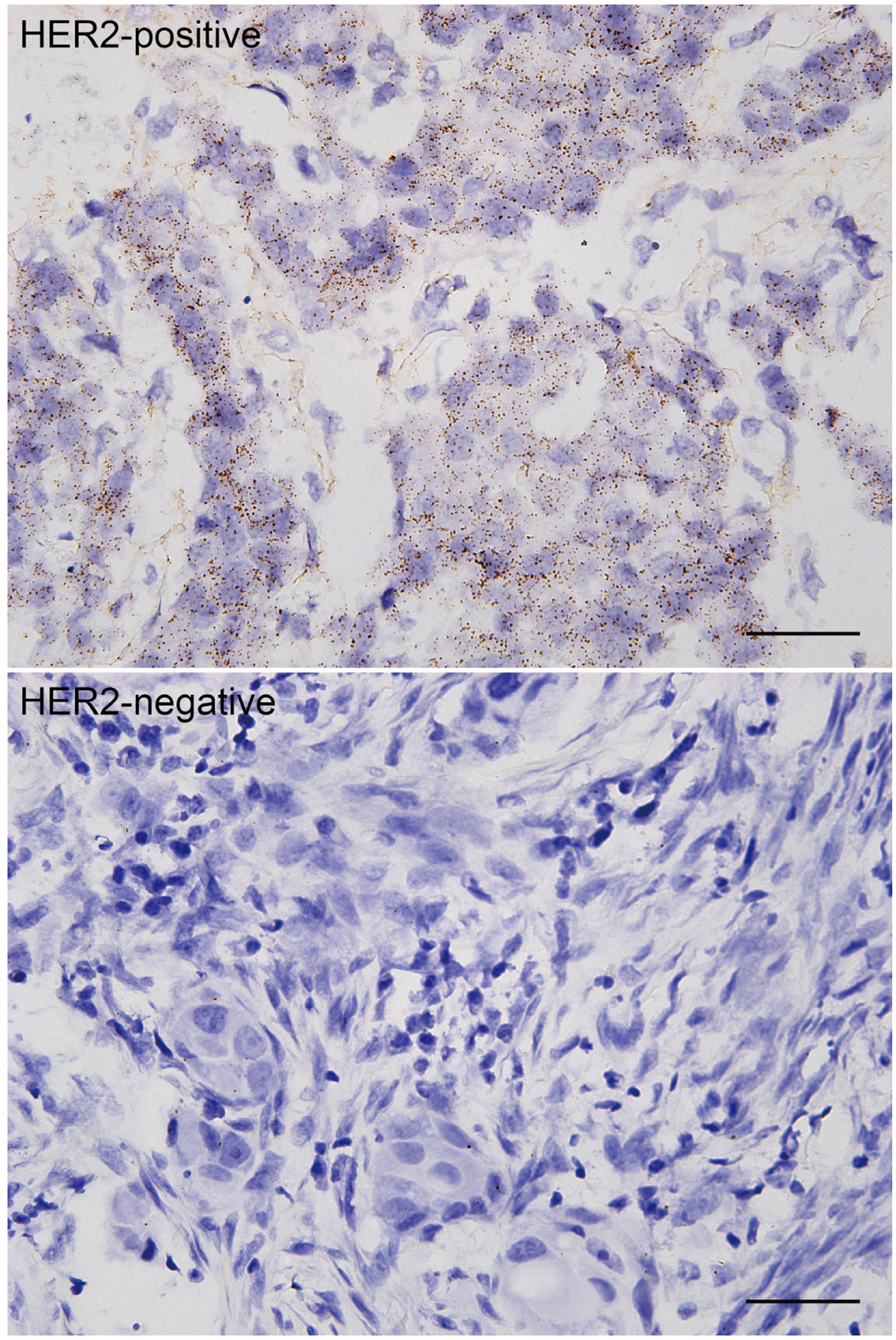

Figure 3. Detection of HER2 mRNA molecules in HER2-positive and HER2-negative breast cancer FFPE tissue sections. Scale bars $=40 \mu \mathrm{m}$.

\section{Data analysis}

Quantitative analysis of detected RNA molecules is achieved by using CellProfiler image analysis software. The images are processed with "Unmixcolors", "EnhanceOrSuppressFeatures", "IndentifyPrimaryObjects", "IndentifySecondaryObjects", "IndentifyPrimaryObjects" and "RelateObjects" modules in turn. To remove the background, the "Unmixcolors" module is used to 
split into hematoxylin and DAB two channels. The "EnhanceOrSuppressFeatures" module is used to highlight DAB staining spots. Finally, the relation of signals with their host cells is identified with the "RelateObjects" module. Then the number of RCPs per cell was listed. Statistical plotting was performed using GraphPad Prism.

\section{$\underline{\text { Notes }}$}

1. For FFPE tissue sections and fresh frozen tissue sections, the pretreatment is different due to different kinds of tissue, including permeabilization and fixation.

2. Oligonucleotides were dissolved and diluted with $1 \mathrm{x}$ TE buffer. The stock concentration of the padlock probe, RCA primer and detection probe were $100 \mu \mathrm{M}, 10 \mu \mathrm{M}$ and $2 \mu \mathrm{M}$ respectively.

3. According to the cell type, adjust the experimental conditions of nucleic counterstaining, such as staining time, concentration of stain fluid.

4. DEPC is heat inactivated before using the solution.

5. Aspirate the solutions from the previous steps before adding a new solution into the chamber.

Troubleshooting: A list of possible reasons for experiment failures and solutions are listed in Table 1.

Table 1. Troubleshooting table

\begin{tabular}{lll}
\hline Problem & Possible reason & Solution \\
\hline & $\begin{array}{l}\text { Padlock probes are not 5'- } \\
\text { phosphorylated }\end{array}$ & $\begin{array}{l}\text { Phosphorylate padlock probes with PNK } \\
\text { Increase the number of padlock probes }\end{array}$ \\
Little or no signal & $\begin{array}{l}\text { The abundance of RNA is low in } \\
\text { cells of interest }\end{array}$ & $\begin{array}{l}\text { that target different hybridization sites on } \\
\text { the same RNA }\end{array}$ \\
Weak staining & $\begin{array}{l}\text { DAB staining solution is not fresh } \\
\text { DAB staining time is too long }\end{array}$ & $\begin{array}{l}\text { Prepare DAB staining solution fresh } \\
\text { Shorten staining time }\end{array}$ \\
& $\begin{array}{l}\text { Endogenous peroxidases are not } \\
\text { blocked }\end{array}$ & $\begin{array}{l}\text { Block endogenous peroxidases with } 3 \% \\
\mathrm{H}_{2} \mathrm{O}_{2} \text { solution }\end{array}$
\end{tabular}

\section{Recipes}

1. Culture media $(50 \mathrm{ml})$

$45 \mathrm{ml}$ serum-free medium

$5 \mathrm{ml}$ fetal bovine serum

$0.5 \mathrm{ml}$ Penicillin-Streptomycin Solution

Store at $4{ }^{\circ} \mathrm{C}$ 
2. $10 x \mathrm{PBS}(500 \mathrm{ml}), \mathrm{pH} 6.8$

$40 \mathrm{~g} \mathrm{NaCl}$

$1 \mathrm{~g} \mathrm{KCl}$

$7.2 \mathrm{~g} \mathrm{Na}_{2} \mathrm{HPO}_{4}$

$1.2 \mathrm{~g} \mathrm{KH}_{2} \mathrm{PO}_{4}$

$500 \mathrm{ml}$ ultrapure water

Filter the solution using $0.22 \mu \mathrm{m}$ membrane filter

Prepare fresh

3. $1 \times$ DEPC-PBS ( $1 \mathrm{~L}), \mathrm{pH} 7.4$

$100 \mathrm{ml} 10 x$ PBS

$900 \mathrm{ml}$ ultrapure water

$1 \mathrm{ml} \mathrm{DEPC}$

Store at $4{ }^{\circ} \mathrm{C}$

4. $1 \times$ DEPC-PBST ( $1 \mathrm{~L})$

1 L DEPC-PBS

$0.5 \mathrm{ml}$ Tween-20

Store at $4{ }^{\circ} \mathrm{C}$

5. $4 \%(w / v)$ PFA $(500 \mathrm{ml})$

For a $4 \%$ paraformaldehyde solution:

a. Add $20 \mathrm{~g}$ of EM grade paraformaldehyde to $480 \mathrm{ml}$ of $1 \times$ DEPC-PBS

b. Add $5 \mathrm{ml}$ of $5 \mathrm{M} \mathrm{NaOH}$ and stir gently on a heating block at $\sim 30{ }^{\circ} \mathrm{C}$ until the paraformaldehyde is dissolved

c. Allow the mixture to cool to room temperature and adjust the $\mathrm{pH}$ to 7.4 with $\mathrm{HCl}$

d. Then adjust the final volume to $500 \mathrm{ml}$ with $1 \times$ DEPC-PBS

e. Filter the solution through a $0.22 \mu \mathrm{m}$ membrane filter to remove any particulate matter

f. Make the paraformaldehyde solution fresh prior to use, or store in aliquots at $-20{ }^{\circ} \mathrm{C}$ for several months. Avoid repeated freeze/thawing

6. $1 \times$ TE buffer $(100 \mathrm{ml}), \mathrm{pH} 8.0$

$1 \mathrm{ml} 1 \mathrm{M}$ Tris- $\mathrm{HCl}(\mathrm{pH} 8.0)$

$0.2 \mathrm{ml} 0.5 \mathrm{M}$ EDTA (pH 8.0)

$98.8 \mathrm{ml} \mathrm{DEPC}-\mathrm{H}_{2} \mathrm{O}$

Filter the solution using $0.22 \mu \mathrm{m}$ membrane filter

Store at $4{ }^{\circ} \mathrm{C}$

7. $0.5 \%(\mathrm{v} / \mathrm{v})$ Triton $\mathrm{X}-100(5 \mathrm{ml})$

$25 \mu \mathrm{l}$ Triton X-100

$4.975 \mathrm{ml} \mathrm{DEPC}-\mathrm{H}_{2} \mathrm{O}$

Store at RT

8. $3 \%(w / v) \mathrm{H}_{2} \mathrm{O}_{2}$ solution $(50 \mu \mathrm{l})$

$5 \mu \mathrm{l} 30 \%(w / v) \mathrm{H}_{2} \mathrm{O}_{2}$ 
$45 \mu \mathrm{IDEPC}-\mathrm{H}_{2} \mathrm{O}$

Prepare fresh

9. $2 x$ hybridization buffer $(5 \mathrm{ml})$

$3 \mathrm{ml} 20 \mathrm{xSC}$

$1 \mathrm{ml}$ Formamide

$1 \mathrm{ml}$ DEPC- $\mathrm{H}_{2} \mathrm{O}$

Store at RT

10. Washing buffer $(15 \mathrm{ml})$

$1.5 \mathrm{ml} 20 \times \mathrm{SSC}$

$3 \mathrm{ml}$ Formamide

$10.5 \mathrm{ml}$ DEPC- $\mathrm{H}_{2} \mathrm{O}$

Store at RT

11. $2 x$ detection buffer $(5 \mathrm{ml})$

$1 \mathrm{ml} 20 x \mathrm{SSC}$

$5 \mu \mathrm{l}$ Tween-20

$0.2 \mathrm{ml} 20 \mathrm{mg} / \mathrm{ml} \mathrm{BSA}$

$3.975 \mathrm{ml} \mathrm{DEPC}-\mathrm{H}_{2} \mathrm{O}$

Store at $4{ }^{\circ} \mathrm{C}$

12. Staining buffer $(50 \mu \mathrm{l})$

$45 \mu \mathrm{LAB}$ buffer

$2.5 \mu \mathrm{l} 20 \mathrm{x}$ DAB substrate solution

$2.5 \mu \mathrm{l} 20 \mathrm{x}$ DAB chromogen solution

Prepare fresh

13. $0.1 \%$ hydrochloric acid-ethanol $(5 \mathrm{ml})$

$50 \mu$ hydrochloric acid

$3.713 \mathrm{ml}$ ethanol

$1.237 \mathrm{ml} \mathrm{DEPC}-\mathrm{H}_{2} \mathrm{O}$

Store at RT

14. Hematoxylin Staining Solution $(50 \mathrm{ml})$

a. Dissolve $0.1 \mathrm{~g}$ hematoxylin with $12.5 \mathrm{ml}$ ethanol

b. Dissolve $0.85 \mathrm{~g}$ aluminum potassium sulfate dodecahydrate with $37.5 \mathrm{ml} \mathrm{DEPC}-\mathrm{H}_{2} \mathrm{O}$

c. Then mix the two solutions

d. After hematoxylin is oxidized to a purplish red by adding $10 \mathrm{mg}$ sodium iodate, add $0.5 \mathrm{ml}$ acetate

e. Filter the solution using $0.22 \mu \mathrm{m}$ membrane filter. Store at RT

f. Concentration of hematoxylin staining solution can be diluted with $D E P C-\mathrm{H}_{2} \mathrm{O}$

15. $25 \mathrm{mM}$ dNTP $(100 \mu \mathrm{l})$

$25 \mu \mathrm{l} 100 \mathrm{mM}$ ATP

$25 \mu \mathrm{l} 100 \mathrm{mM}$ GTP 
$25 \mu \mathrm{l} 100 \mathrm{mM}$ CTP

$25 \mu \mathrm{l} 100 \mathrm{mM}$ TTP

Store at $-20^{\circ} \mathrm{C}$

\section{Competing interests}

Authors declare no conflicts of interest or competing interests.

\section{Acknowledgments}

This work was supported by the funds from the National Natural Science Foundation of China (31770927), the National Key Research and Development Program of China (2017YFA0106800), the Natural Science Foundation of Fujian Province, and the Scientific Research Funds of Huaqiao University.

\section{$\underline{\text { References }}$}

1. Banér, J., Nilsson, M., Mendel-Hartvig, M. and Landegren, U. (1998). Signal amplification of padlock probes by rolling circle replication. Nucleic Acids Res 26(22): 5073-5078.

2. Battich, N., Stoeger, T. and Pelkmans, L. (2013). Image-based transcriptomics in thousands of single human cells at single-molecule resolution. Nat Methods 10(11): 1127-1133.

3. Crosetto, N., Bienko, M. and van Oudenaarden, A. (2015). Spatially resolved transcriptomics and beyond. Nat Rev Genet 16(1): 57-66.

4. Femino, A. M., Fay, F. S., Fogarty, K. and Singer, R. H. (1998). Visualization of single RNA transcripts in situ. Science 280(5363): 585-590.

5. Jiang, M., Liu, L., Hong, C., Chen, D., Yao, X., Chen, X., Lin, C. and Ke, R. (2019). Single molecule chromogenic in situ hybridization assay for RNA visualization in fixed cells and tissues. RNA 25(8): 1038-1046.

6. Larsson, C., Grundberg, I., Soderberg, O. and Nilsson, M. (2010). In situ detection and genotyping of individual mRNA molecules. Nat Methods 7(5): 395-397.

7. Nilsson, M., Malmgren, H., Samiotaki, M., Kwiatkowski, M., Chowdhary, B. P. and Landegren, U. (1994). Padlock probes: circularizing oligonucleotides for localized DNA detection. Science 265(5181): 2085-2088.

8. Shah, S., Lubeck, E., Schwarzkopf, M., He, T. F., Greenbaum, A., Sohn, C. H., Lignell, A., Choi, H. M., Gradinaru, V., Pierce, N. A. and Cai, L. (2016). Single-molecule RNA detection at depth by hybridization chain reaction and tissue hydrogel embedding and clearing. Development 143(15): 2862-2867. 
9. Wang, F., Flanagan, J., Su, N., Wang, L. C., Bui, S., Nielson, A., Wu, X., Vo, H. T., Ma, X. J. and Luo, Y. (2012). RNAscope: a novel in situ RNA analysis platform for formalin-fixed, paraffinembedded tissues. J Mol Diagn 14(1): 22-29. 